\title{
PODE A EUROPA SE DESARMAR? 1
}

\section{CAN EUROPE DISARM?}

\section{¿PUEDE EUROPA DESARMARSE?}

\author{
Friedrich Engels ${ }^{2}$
}

\section{Prefácio}

Os artigos reimpressos aqui foram publicados no jornal de Berlim Vorwärts em março de 1893, durante o debate do Reichstag sobre o Projeto de Lei Militar.

Neles eu parto da suposição cuja cada vez mais a aceitação geral é maior: que o sistema de exércitos permanentes foi levado a tais extremos por toda a Europa que deve trazer ruína econômica aos povos por conta do fardo militar ou então degenerar em uma guerra geral de extermínio, a menos que os exércitos permanentes sejam transformados em tempo hábil em uma milícia baseada no armamento universal do povo.

Tento provar que essa transformação é possível neste exato momento, mesmo para os governos atuais e a situação política atual. Portanto, tomo essa situação como minha base e, por enquanto, proponho apenas os meios que poderiam ser adotados por qualquer governo da época sem comprometer a segurança nacional. Eu simplesmente procuro estabelecer que, de um ponto de vista puramente militar, não há barreiras para impedir a abolição gradual de exércitos permanentes; e que, se esses exércitos são mantidos, é por razões políticas e não militares - que, em uma palavra, os exércitos têm a intenção de proteger não tanto contra o inimigo externo mas contra o interno.

Contudo, considero a redução gradual do termo de serviço via tratado internacional, o que forma o núcleo do meu argumento, como a maneira mais simples e rápida possível de efetuar a transição geral de um exército permanente para o armamento das pessoas organizadas enquanto uma milícia. Os termos desse tratado variariam naturalmente de acordo com a natureza dos governos contratantes e a situação política do dia. $\mathrm{E}$ as coisas não poderiam ser mais favoráveis do que atualmente; se é possível ainda hoje estabelecer um prazo máximo de serviço de dois anos como ponto de partida, em alguns anos poderá ser possível escolher um período de tempo muito mais curto.

Ao tornar o treinamento físico e militar de todos os jovens do sexo masculino uma condição essencial para a transição para o novo sistema, excluo expressamente a possibilidade de o sistema militar proposto aqui ser confundido com qualquer outra milícia existente, por exemplo, aquela da Suíça. 
Londres, 28 de março de 1893

F. Engels

I

Nos últimos vinte e cinco anos, toda a Europa vem se armando em uma escala até então sem precedentes. Toda grande potência está tentando superar outra em força militar e prontidão para a guerra. Alemanha, França e Rússia estão se esgotando em seus esforços para superar um ao outro. Neste exato momento, o governo alemão está exigindo do povo um novo esforço tão tremendo que até o manso atual Reichstag se afasta dele. Não seria tolice, então, falar em desarmamento?

E, no entanto, em todos os países, as pessoas das classes que quase exclusivamente têm que fornecer a maior parte dos soldados e pagar a maior parte dos impostos estão clamando por desarmamento. $\mathrm{E}$, de igual maneira, em todos os lugares o esforço chegou ao estágio em que sua força - aqui os recrutas, ali o dinheiro, em algum outro lugar ambos - começa a falhar. Não há escapatória deste beco sem saída exceto por uma guerra de destruição como o mundo nunca viu?

Eu mantenho: o desarmamento e, portanto, uma garantia de paz é possível, e comparativamente fácil de executar, e a Alemanha, mais do que qualquer outro estado civilizado, tem o poder e a missão de realizá-lo.

Após a guerra de 1870-71, a superioridade do sistema de serviço militar obrigatório universal com uma reserva e um Landwehr ${ }^{3}$ - mesmo em sua forma atrofiada da Prússia - sobre o sistema de recrutamento por procuração havia sido demonstrada conclusivamente. Todos os países continentais o adotaram de formas mais ou menos modificadas. Não haveria nenhum grande dano nisso. Um exército que tem sua principal reserva em homens casados de meia-idade é, por natureza, menos ofensivo do que o exército conscrito de Luís Napoleão, que era permeado por procuradores pagos - soldados profissionais recrutados. Mas então veio a anexação da Alsácia-Lorena, que transformou a Paz de Frankfurt em um mero cessar-fogo para a França, como a Paz de Tilsit fora para a Prússia. E assim começou a corrida armamentista febril entre a França e a Alemanha, para a qual Rússia, Áustria e Itália também foram gradualmente atraídas.

Para começar, o termo de serviço obrigatório no Landwehr foi estendido. Na França, o exército territorial adquiriu uma reserva de homens mais velhos; na Alemanha, o segundo recrutamento do Landwehr e até o Landsturm ${ }^{4}$ foram revividos. E assim foi, passo a passo, até que o limite de idade estabelecido pela natureza fosse atingido e até excedido.

Então, o recrutamento foi intensificado e os novos quadros de treinamento que isto tornou necessário foram montados; mas aqui novamente o limite foi quase ou totalmente atingido e, na França, foi excedido. As últimas entradas de alistamento do exército francês já incluem um grande número de jovens que ainda não estão - ou nem são - à altura das dificuldades do serviço. Os oficiais ingleses, imparciais neste ponto, que participaram da grande manobra em Champagne em 1891 e reconheceram a alta eficiência do atual exército francês, de forma admiradora e às vezes generosamente, relatam por unanimidade que um número excessivamente grande de jovens soldados abandonou o curso de marchas e exercícios de combate. 
$\mathrm{Na}$ Alemanha, ainda não esgotamos nossas reservas de homens aptos para o serviço militar, mas remediar isso é precisamente o objetivo do novo projeto de lei militar. Em resumo, mesmo neste aspecto, estamos nos aproximando dos limites de nossos poderes.

Agora, o aspecto moderno e revolucionário do sistema militar prussiano consiste precisamente na exigência de que a força de todo homem hábil seja posta a serviço da defesa nacional enquanto ele for capaz de portar armas. E a única coisa revolucionária que pode ser discernida em todo o desenvolvimento militar desde 1870 é o próprio fato de ter sido considerado necessário - muitas vezes com certa relutância efetivamente atender cada vez mais essa demanda, que até agora só era cumprida na fantasia chauvinista. Nem o tempo de disponibilidade para o serviço nem o alistamento de todos os jovens capazes podem ser questionados hoje, principalmente pela Alemanha e menos ainda pelo Partido Social-Democrata, que, pelo contrário, é a única força capaz de traduzir também plenamente essa demanda em prática.

Consequentemente, resta apenas um ponto em que a necessidade de desarmamento pode aplicar a alavanca: o tempo de serviço na ativa. E esse é, de fato, o ponto arquimediano: a regulamentação internacional, pelas grandes potências do Continente, do prazo máximo de serviço na ativa para todos os ramos do serviço militar, inicialmente por dois anos, na medida em que me consta - mas com a condição de uma redução imediata ainda maior, assim que as pessoas se convencerem da possibilidade e com o sistema de milícias como objetivo final. E mantenho que a Alemanha, em particular, está mais apta a fazer essa proposta e que a Alemanha lucrará mais do que qualquer outra nação ao fazê-la, mesmo que seja rejeitada.

\section{II}

A regulamentação internacional do prazo máximo de serviço na ativa afetaria igualmente os exércitos de todos os poderes. Supõe-se geralmente que, em exércitos cujos homens nunca foram atacados, para a fase inicial de uma campanha, o tempo de serviço ativo - dentro de certos limites - fornece a melhor medida de sua adequação em todas as situações de guerra, particularmente para estratégias e táticas de ataque. Nossos guerreiros de 1870 tinham experiência suficiente da furia francese ${ }^{5}$, do ataque de baioneta da antiga infantaria imperial e a força total dos ataques de cavalaria em Wörth e Sedan; mas em Spichern, logo no início da guerra, eles também demonstraram que podiam expulsar essa mesma infantaria de uma posição forte - mesmo que em menor número.

Se conseguirmos estabelecer um limite máximo para seus tempos de serviço internacionalmente, a capacidade relativa dos vários exércitos permanecerá aproximadamente o que é hoje. O que um perde em potencial imediato, os outros também perdem. Na medida em que um ataque surpresa de um estado contra outro for excluído, continuará sendo assim, na mesma extensão. A diferença no tempo de serviço ativo entre a França e a Alemanha, por exemplo, até agora não tem sido de grande importância; mesmo sob o prazo reduzido de serviço, tudo dependeria de como o termo de serviço acordado fosse usado em cada um dos exércitos, exatamente como hoje. Além disso, a força relativa dos dois exércitos corresponderia à proporção entre as populações dos dois países. Uma vez efetivamente introduzido o serviço militar obrigatório universal, em países de desenvolvimento econômico aproximadamente igual (o que determina 
a porcentagem dos impróprios ao serviço), o tamanho da população será sempre a medida da força das forças armadas. Então não haverá mais truques como os truques prussianos de 1813; esse creme terá sido desnatado.

Mas muita coisa depende de como o tempo de serviço estabelecido é utilizado. E, nesse assunto, há homens em quase todos os exércitos que poderiam contar uma história ou duas, se lhes fosse permitido, pois a escassez de dinheiro em todos os lugares forçou os exércitos a dar a uma proporção de seus recrutas um treinamento "improvisado" em poucos meses. Ademais, eles precisam se restringir ao essencial, uma grande quantidade de bobagens tradicionais é descartada e se descobre, para sua surpresa, o pouco tempo necessário para transformar um jovem toleravelmente bem constituído em um soldado. Bebel relatou no Reichstag como isso surpreendeu os oficiais de treinamento da Ersatzreserve alemã ${ }^{6}$. No exército austríaco, há muitos oficiais que sustentam que o Landwehr, que tem o mesmo termo de serviço que a Ersatzreserve alemã, é melhor que a própria linha. Não me admira. Ali falta o tempo que é desperdiçado na linha nas idiotices tradicionais e, portanto, santificadas - e que por essa mesma razão na ersatz̧reserve não é desperdiçado.

Os regulamentos de infantaria alemães de 1888 limitam as formações táticas para a batalha ao essencial. Não contém nada de novo; a capacidade de combate em todas as situações invertidas já havia sido introduzida pelos austríacos desde 1859; a formação de todas as colunas do batalhão por meio de uma simples combinação de quatro colunas da companhia havia sido introduzida na mesma época pelos darmessianos $^{7}$, que tiveram que aceitar novamente essa formação racional ser proibida pelos prussianos após $1866^{8}$. Por outro lado, novos regulamentos acabam com um imenso emaranhado de cerimônias antediluvianas que eram tão inúteis quanto sacrossantas; por essa razão ao menos, não tenho motivo algum para encontrar falhas neles. Pois depois da guerra de 1870, permiti-me o luxo de elaborar um plano de formações e movimentos fechados de companhias e batalhões apropriados à guerra atual, e não fiquei nem um pouco surpreso ao encontrar esse pedaço do "estado do futuro" implementado em quase todos os aspectos nas seções relevantes dos novos regulamentos.

Mas os regulamentos são uma coisa e colocá-los em prática outra. As martinets ${ }^{9}$, que sempre floresceram no exército prussiano em tempos de paz, reintroduzem o desperdício de tempo abolido nas instruções pela porta dos fundos dos campos de treinamento de paradas. De fato, o exercício de desfile é de vital importância para contrabalançar a irregularidade da ordem de batalha dispersa, como o único meio de estabelecer a verdadeira disciplina etc. etc. Isso equivale a dizer que a ordem e a disciplina só podem ser estabelecidas fazendo os homens praticarem coisas totalmente inúteis. A abolição do "passo de ganso" por si só faria semanas inteiras disponíveis para exercícios racionais, além do fato de que oficiais estrangeiros finalmente poderiam assistir a uma revista alemã sem cair na gargalhada.

Outra instituição obsoleta semelhante é o serviço de sentinela, que, segundo uma antiga noção tradicional também serve para desenvolver a inteligência e, especialmente, o pensamento independente dos homens, ensinando-lhes a arte - caso ainda não estejam familiarizados com ela - de ficar de guarda e não pensar em nada por duas horas. Tendo em vista o presente costume universal de praticar serviço de posto avançado no campo, o serviço de sentinela na cidade, onde há todo tipo de policiais de segurança, tornou- 
se totalmente sem sentido, e sua abolição resultaria em um ganho de pelo menos $20 \%$ no prazo efetivo de serviço militar e garantiria a segurança nas ruas para os civis.

E existem muitos soldados em todos os lugares que, sob todos os tipos de pretextos, prestam o menor serviço possível: artesãos de companhias, ajudantes de ordens, etc. Há muito espaço para mudanças aqui.

Sim - mas e a cavalaria? Certamente eles devem ter um período de serviço mais longo? - Isso é certamente desejável se alguém estiver lidando com recrutas que não sabem andar nem cuidar de um cavalo. Mas há muito espaço para mudanças aqui também. Se as rações de cavalos não fossem tão escassamente proporcionadas - os cavalos precisam ser alimentados especialmente para as manobras para atingir sua força normal! - e se cada esquadrão tivesse um número extra de cavalos disponível para que os homens pudessem praticar na sela com mais frequência e por períodos mais longos - em suma, se um esforço sério for feito para compensar o menor período de serviço pela busca mais intensiva de itens essenciais e pela eliminação de coisas supérfluas, logo se descobriria que é possível gerenciar nessa maneira também. Mesmo em situações difíceis, nas quais tanto estresse foi colocado e há uma necessidade vital da qual eu concordo prontamente, formas e meios podem ser encontrados. E, de qualquer maneira, não há nada que impeça a retenção e a extensão do sistema de voluntários de três ou quatro anos ou de soldados realistados novamente para tropas de cavalaria, pelo tempo que for considerado necessário - em troca das compensações correspondentes na disponibilidade de serviço para a reserva e o Landwehr, sem os quais tais coisas não serão atingidas.

III

É um contraste peculiar: nossos soldados de alto escalão são geralmente tão terrivelmente conservadores, precisamente em seu próprio campo, e ainda hoje não há quase nenhum outro domínio tão revolucionário quanto o militar. O cano liso de seis libras e o obus de sete libras que eu manuseava perto do Kupfergraben ${ }^{10}$ nos velhos tempos e as atuais armas de carregamento de culatra, a pistola de grande calibre de fibra daqueles dias e os modernos carregadores de culatra de $5 \mathrm{~mm}$ parecem separados por séculos; e ainda não há fim para isso, todos os dias a tecnologia ainda lança implacavelmente suas últimas inovações. Agora, até descarta a romântica fumaça de pó, dando à batalha um caráter totalmente diferente e um percurso que não se pode calcular com antecedência. No entanto, devemos cada vez mais aceitar esses fatores incalculáveis em meio a essa revolução incessante da base técnica da guerra.

Até quarenta anos atrás, o efetivo campo de tiro da infantaria não se estendia mais do que 300 passos, distância a qual um único homem poderia sobreviver incólume a saraivada de um batalhão inteiro, desde que os homens estivessem realmente mirando nele. Quanto ao campo de tiro da artilharia de campo, era praticamente ineficaz mesmo entre 1.500 e 1.800 passos. Na Guerra Franco-Prussiana, o alcance efetivo dos fuzis era de 600 a 1.000 passos, o da artilharia de 3.000 a 4.000 passos, no máximo. Mas os novos rifles de pequeno calibre, ainda não experimentados na guerra, têm um alcance aproximado ao da artilharia; seus projéteis têm de quatro a seis vezes a força de penetração; o rifle de repetição fornece hoje a uma seção o 
mesmo poder de fogo que uma companhia inteira costumava ter; a artilharia, embora não possa se orgulhar de um aumento semelhante no alcance de tiro, carregou suas munições com explosivos totalmente novos de efeito inédito; embora ainda seja incerto quem terá que sofrer esse efeito, o alvejado ou o atirador.

E em meio a essa revolução incessante e sempre acelerada de todo o sistema militar, somos confrontados com autoridades militares que há cinco anos ainda inculcavam em suas tropas todas as cerimônias convencionais e contorções artificiais das táticas lineares do velho Fritz ${ }^{11}$, que desapareceram do campo de batalha há muito tempo, e continuaram a reverenciar os regulamentos pelos quais você ainda pode ser espancado porque marchou para a direita e não havia espaço para a formação à esquerda! As autoridades que até hoje não se atrevem a questionar os botões brilhantes e os acessórios de metal do equipamento dos soldados - o mesmo que usar ímãs para atrair balas de $5 \mathrm{~mm}$ - que colocam os uhlans em ação com amplos gibões vermelhos e os cuirassiers reconhecidamente sem couraças - finalmente ! - mas com roupas de batalha brancas, e depois de muita reflexão decidiram sacrificar no altar da pátria as dragonas (que eram ainda mais sagradas por serem de um gosto tão assustador) - em vez de o próprio portador de dragonas.

Parece-me que não é do interesse do povo alemão nem do exército alemão que essa superstição conservadora permaneça no controle do exército em meio à revolução técnica que está surgindo ao seu redor. Precisamos de mentes mais arrojadas e ousadas, e eu ficaria muito enganado se não houvesse muitas dessas entre nossos oficiais mais capazes, muitos desejosos de serem libertados da rotina e do pedantismo que novamente se pululou nos últimos vinte anos de paz. Mas até que encontrem a coragem e a oportunidade de afirmar suas convicções, o resto de nós terá que entrar na brecha e fazer o possível para provar que também aprendemos algo no exército.

Além disso, tentei demonstrar acima que o mandato de dois anos pode ser posto em prática agora em todos os setores do serviço, se os homens aprenderem o que precisam saber sobre a guerra e forem poupados das antiguidades tradicionais que consomem tempo. Mas afirmei desde o início que não deveria parar em dois anos. Em vez disso, a proposta de um período de serviço internacional de dois anos deveria ser vista simplesmente como o primeiro passo para uma redução gradual no prazo de serviço - digamos, dezoito meses para começar, dois verões e um inverno - depois um ano - então...? É aqui que começa o estado do futuro, o sistema de milícias não adulterado, e voltaremos a isso assim que a coisa realmente tiver sido posta em movimento.

E isso, colocar a coisa em movimento, é o mais importante de tudo. Ao primeiro se deparar com o fato de que a redução do termo de serviço é uma necessidade para a existência econômica de todos os países e para a preservação da paz europeia, o próximo ganho a ser alcançado é a percepção de que a ênfase no treinamento militar deveria ser colocada na educação da juventude.

Quando voltei para o Reno, após dez anos de exílio ${ }^{12}$, fiquei agradavelmente surpreso ao ver barras paralelas e horizontais instaladas em todos os lugares nos pátios das escolas das vilas. Até agora, tudo bem: infelizmente não foi muito longe. $\mathrm{O}$ aparelho foi adquirido de acordo com as instruções, da maneira antiga e prussiana, mas quando se tratava de usá-lo, havia sempre algum tipo de obstáculo. Eram outros quinhentos - na verdade, geralmente nunca se chegava a isso. É pedir demais que, finalmente, todo o negócio seja levado 
a sério? Que aos alunos de todas as classes seja ensinado ginástica com e sem aparelhos, sistematicamente e minuciosamente, enquanto seus membros ainda são elásticos e flexíveis, em vez de, como agora, fazer rapazes de vinte anos serem escravizados em vão pelo suor de suas sobrancelhas - e os seus próprios - a fim de tornar seus ossos, músculos e ligamentos rígidos soltos e flexíveis novamente? Qualquer médico lhe dirá que a divisão do trabalho deforma qualquer ser humano sujeito a ela, toda uma série de músculos sendo desenvolvidos à custa de outros e que os efeitos disso variam de acordo com o ramo específico do trabalho, cada trabalho produzindo a sua própria deformidade. Não é então loucura primeiro deixar os homens se deformarem e depois torná-los retos e móveis novamente no exército? Demanda-se um certo grau de percepção que ultrapasse o horizonte oficial para perceber que se obterão soldados três vezes melhores se estes forem protegidos contra essas deformações no momento apropriado, no ensino fundamental e no ensino médio?

Mas isso é apenas o começo. Um menino pode aprender com facilidade a formação e o movimento de uma tropa serrilhada na escola. O estudante fica de pé e caminha ereto por natureza, principalmente quando tem treinamento físico; durante o serviço militar, todos nós observamos a posição de nossos recrutas e o quão difícil é ensinar muitos deles a andar e permanecer eretos. Os movimentos em colunas e em companhias podem ser treinados em qualquer escola e com facilidade desconhecida no exército. O que é uma dificuldade detestável, quase sempre intransponível, para o recruta é um jogo e uma diversão para o estudante. O contato e o senso de direção nas marchas frontais e nas rodas, tão difíceis de obter com os recrutas adultos, são facilmente aprendidos pelos estudantes, assim que o exercício é sistematicamente realizado com eles. Se boa parte do verão fosse dedicada a marchas e exercícios no campo, as mentes e os corpos dos meninos não se beneficiariam menos do que os cofres militares, o que economizaria meses inteiros de tempo de serviço. Caminhadas militares desse tipo são particularmente adequadas para fazer os meninos resolverem os problemas encontrados no serviço ativo, e isso, por sua vez, é altamente apto a desenvolver a inteligência dos alunos e permitir que eles adquiram um treinamento especificamente militar em um período relativamente curto. A prova prática disso foi fornecida pelo meu velho amigo Beust, ele próprio um ex-oficial da Prússia, em sua escola em Zurique. Com o atual estado complicado das questões militares, uma transição para o sistema de milícias é inconcebível sem treinamento militar preparatório para jovens, e é exatamente nesse campo que as experiências bem-sucedidas de Beust são da maior importância.

E agora permita-me fazer uma nota especificamente prussiana. A questão vital que preocupa o estado prussiano é: o que acontecerá com o oficial não comissionado que cumpriu seu tempo? Até agora, ele foi usado como policial, guarda de fronteira, porteiro, balconista, como funcionário público de todo tipo concebível; não existe uma única vaga na burocracia prussiana, por mais humilde que seja, que não tenha sido preenchida por oficiais não comissionados que reivindicam uma indicação no governo. Pois bem: você trabalhou até a exaustão para encontrar posições para os oficiais não comissionados; você insistiu em empurrá-los onde eles não são úteis e usá-los para coisas das quais nada sabem; não passou da hora de encontrarem um lugar em um campo com o qual estejam familiarizados e onde possam realizar um trabalho útil? Eles devem se tornar mestres na escola, mas não na leitura, escrita e aritmética - deixe-os ensinar 
ginástica e exercícios. Isso fará bem a eles e aos meninos. E uma vez que os oficiais não-comissionados sejam transferidos do sigilo do quartel e da jurisdição militar para a luz do dia no pátio da escola e no processo criminal civil, aposto que nossos alunos rebeldes da escola logo ensinarão até aos piores déspotas da caserna boas maneiras.

$I V$

Reservamo-nos o direito de voltar à questão de saber se tal proposta de redução universal, igual e gradual no prazo de serviço tem alguma perspectiva de ser adotada por tratado internacional. Por enquanto, procederemos da suposição de que foi adotada. Seria ela então traduzida do papel para a realidade, seria honestamente realizada por todas as partes?

Certamente, em sua maioria. Em primeiro lugar, não será possível manter em segredo uma maneira de evitá-la que, de qualquer forma, valha a pena. E segundo, a própria população garantirá sua implementação. Ninguém permanece no quartel por vontade própria, se ele for mantido lá além do período prescrito por lei.

No que diz respeito a países individuais, a Áustria e a Itália, assim como os estados de segundo e terceiro escalão que introduziram o serviço militar universal, receberão este tratado como um ato de libertação e terão todo o gosto em aderir a ele em todos os seus detalhes. Discutiremos a Rússia na próxima seção. Mas e a França? E, nessa questão, a França é definitivamente o país decisivo.

Uma vez que a França assine e ratifique o tratado, não resta dúvida de que terá, em geral, de cumpri-lo. Mas vamos admitir que a tendência revanchista existente nas classes proprietárias e na parte da classe trabalhadora que ainda não é socialista possa ganhar vantagem por um momento e provocar violações dos limites do tratado, diretos ou baseados em ninharias. Tais infrações nunca podem, contudo, ser de importância, pois, caso contrário, Paris preferiria revogar o tratado. Mas a Alemanha está na posição privilegiada de poder, generosamente, fechar os olhos a uma trapaça tão pequena. Apesar de todos os esforços louváveis da França para tornar impossível a repetição das derrotas de 1870, a Alemanha está muito mais à frente do que é evidente à primeira vista. Em primeiro lugar, há uma lacuna que cresce anualmente entre as populações, agora totalizando mais de 12 milhões a favor da Alemanha. Em segundo lugar, o fato de o atual sistema militar existir na Prússia há mais de setenta anos; a população se acostumou a ele; foi testado em todos os detalhes em uma longa série de mobilizações; todos os problemas que podem surgir e o modo de resolvê-los foram experimentados na prática e são familiares - vantagens das quais os outros exércitos alemães também se beneficiam. Na França, no entanto, a mobilização geral ainda precisa ser experimentada, e com uma organização que, para esse fim, é muito mais complicada. Em terceiro lugar, no entanto, a instituição antidemocrática de voluntários de um ano encontrou obstáculos insuperáveis na França; os soldados de três anos simplesmente expulsaram os privilegiados de um ano do exército por meio de esquemas. Isso prova até que ponto a consciência política pública na Alemanha e as instituições políticas toleradas por ela ficam para trás das da França. Mas a falha política é, neste caso, uma vantagem militar. É indiscutível que nenhum país, em relação à sua população, envia um número tão grande de jovens através 
de suas escolas ginasiais e secundárias como a Alemanha, e assim a instituição de voluntários de um ano, por mais que seja antidemocrática e politicamente censurável, fornece ao comando do exército um excelente meio de dar à maioria desses jovens (que já receberam um treinamento geral adequado) um treinamento militar para servir como oficiais. A campanha de 1866 ilustrou isso pela primeira vez, mas desde então, e particularmente desde 1871, esse aspecto da força militar da Alemanha foi especialmente promovido, de fato quase em excesso. E mesmo que muitos oficiais da reserva alemães tenham feito o possível para tornar sua posição um motivo de chacota, ainda não há dúvida de que, como um corpo, são militarmente superiores, homem a homem, a suas contrapartes francesas e, ainda mais importante, a Alemanha possui entre seus reservistas e territorialistas uma porcentagem muito maior de homens qualificados para servir como oficiais do que qualquer outro país.

Essa abundância peculiar de oficiais permite à Alemanha reunir um número desproporcionalmente maior de novas formações, já treinadas em tempo de paz, do que qualquer outro país. De acordo com a alegação de Richter (Freisinnige Zeitung, 26 de novembro de $1892{ }^{13}$ ), que, até onde eu sei, não foi refutada nem no Reichstag nem na comissão militar, cada regimento de infantaria alemão poderá fornecer um regimento de reserva móvel, dois batalhões do Landwehr e dois batalhões de Ersatzreserve para ação em guerra. Assim, cada três batalhões fornecem dez, ou os 519 batalhões dos 173 regimentos em tempos de paz se transformam em 1.730 batalhões em tempo de guerra, sem contar com fuzileiros e artilheiros. E em tão pouco tempo que nenhum outro país é capaz de chegar nem perto disto.

Os oficiais de reserva franceses, como um deles me admitiu, são muito menos numerosos; no entanto, eles devem ser suficientes para preencher os postos das novas formações previstas pelas publicações oficiais. O que é mais importante, esse homem confessou que metade desses oficiais não tem muita utilidade. As novas formações em questão estão, no entanto, muito longe de igualar o que se diz que a Alemanha é capaz de alcançar. E ainda assim, todos os oficiais que a França é capaz de reunir até então já serão utilizados, enquanto a Alemanha ainda manterá alguns deles na reserva.

Em todas as guerras até agora, houve uma falta de oficiais após alguns meses de campanha. Com todos os outros países, esse ainda seria o caso até hoje. Só a Alemanha tem um suprimento inesgotável de oficiais. Sendo assim, não poderíamos fechar os olhos se os franceses ocasionalmente treinassem seus homens duas ou três semanas a mais do que o estipulado no tratado?

$\boldsymbol{V}$

Agora chegamos à Rússia. Francamente falando, faz pouca diferença se a Rússia adere a um tratado sobre a redução gradual e igualitária do termo de serviço, ou mesmo entra em um. De fato, no que diz respeito à questão em pauta, podemos desconsiderar a Rússia quase inteiramente, pelas razões expostas abaixo.

Embora o Império Russo abarque mais de cem milhões de pessoas, facilmente o dobro do Império Alemão, está longe de possuir uma força militar ofensiva remotamente próxima à da Alemanha. Os cinquenta milhões de pessoas da Alemanha estão amontoados em uma área de 540.000 quilômetros 
quadrados; os, no máximo, 90 a 100 milhões de pessoas na Rússia que entram em consideração para nós militarmente estão dispersos sobre mais de 3,5 milhões de quilômetros quadrados, em uma estimativa moderada; a vantagem dos alemães devido a essa densidade populacional muito maior é aumentada ainda mais pela rede ferroviária incomparavelmente melhor. Apesar disso, permanece o fato de que cem milhões podem, a longo prazo, fornecer mais soldados do que cinquenta. Como as coisas estão atualmente levará muito tempo até que isso aconteça; mas acontecerá eventualmente. E então o que?

Um exército precisa não apenas de recrutas, mas também de oficiais. E, a esse respeito, a posição na Rússia parece muito ruim. Na Rússia, apenas a nobreza e os cidadãos das cidades são considerados para o posto de oficial. A nobreza é comparativamente muito pequena em números; existem poucas cidades um homem a cada dez no máximo vive em uma cidade - e dessas cidades apenas muito poucas merecem este nome. O número de escolas secundárias e dos alunos que as frequentam é extremamente pequeno. De onde vêm os oficiais de todas as tropas comuns?

O que é bom para uns é ruim para outros. O sistema de serviço militar universal pressupõe um certo grau de desenvolvimento econômico e intelectual; onde isso está faltando, o sistema causa mais mal do que bem. E esse é obviamente o caso da Rússia.

Primeiro, leva um tempo comparativamente mais longo para transformar em um soldado treinado um recruta russo comum. O soldado russo é de bravura inquestionável. Enquanto o ataque das tropas seriadas de infantaria era taticamente decisivo, ele estava em seu elemento. Toda a sua experiência de vida o levou a confiar na união com seus camaradas. Nas aldeias, a comunidade semi-comunista, nas cidades, o trabalho cooperativo do artel ${ }^{14}$, em todo lugar о круговая порука ${ }^{15}$, a responsabilidade mútua dos camaradas; em suma, um estado da sociedade que palpavelmente aponta para a coesão, a fonte de toda salvação, por um lado, e a solidão impotente do indivíduo isolado deixado por sua própria iniciativa, por outro. O russo mantém esse caráter mesmo no exército; os batalhões reunidos são quase impossíveis de se romper, quanto maior o perigo, mais fortes os pedaços se agrupam. Mas esse instinto de fechar fileiras, que ainda era de valor inestimável na época das campanhas napoleônicas e compensava muitos aspectos menos úteis do soldado russo, é hoje definitivamente um perigo. Hoje, as massas em fileiras fechadas desapareceram da linha de batalha; hoje é uma questão de reunir grupos dispersos de soldados de infantaria, nos quais as tropas das mais diversas unidades estão todas confusas e cujo comando com frequência e rapidez é trocado entre oficiais completamente desconhecidos para a maioria dos homens; hoje todo soldado deve ser capaz de fazer o que deve ser feito por si próprio a qualquer momento em particular, embora sem perder o senso de pertencer ao todo. Esse senso de coesão não pode ser facilitado pelo instinto primitivo de manada do russo, mas apenas pelo desenvolvimento da inteligência de cada indivíduo. As condições essenciais para isso só podem ser encontradas em um estágio de civilização marcado por um desenvolvimento "individualista" mais elevado, como o existente nas nações capitalistas do Ocidente. O carregador de culatra repetitivo de pequeno diâmetro e o pó de baixa fumaça transformaram a qualidade que até então era a maior força do exército russo em uma de suas maiores fraquezas. Destarte, hoje em dia vai demorar ainda mais do que antes para tornar o recruta russo em um soldado apto para a batalha, e ele não mais será capaz de igualar minimamente os soldados do Ocidente. 
Mas, em segundo lugar: de onde os oficiais virão para dar a todas essas novas formações uma estrutura em tempo de guerra? Se mesmo a França está tendo problemas para encontrar um número suficiente de oficiais, como a Rússia conseguirá? A Rússia, onde a população instruída, que sozinha pode fornecer oficiais competentes, constitui uma porcentagem desproporcionalmente pequena do total, e ainda assim os soldados, mesmo os soldados treinados, precisam de uma porcentagem maior de oficiais do que em outros exércitos?

E terceiro: com o notório e amplo sistema de peculato e roubo por parte dos funcionários públicos na Rússia, e com muita frequência também dos oficiais, como é que uma mobilização deve ocorrer? Em todas as guerras anteriores da Rússia, descobriu-se imediatamente que mesmo parte do exército em tempos de paz e seus estoques de equipamentos existiam apenas no papel. Como eles gerenciarão, então, quando os reservistas de licença e о ополчение (Landwehr) ${ }^{16}$ devem se unir às suas unidades e estar equipados com uniformes, armas e munições? A menos que tudo corra bem durante a mobilização, a menos que tudo esteja disponível na hora e no lugar certos, há confusão absoluta. Mas como as coisas correrão bem se tudo passa pelas mãos de чино́вники ${ }^{17}$ russos corruptos e ladrões? A mobilização russa - será um espetáculo adequado para os deuses!

Tudo considerado: por razões puramente militares, podemos permitir que os russos convoquem tantos soldados quanto queiram e os mantenham na ativa enquanto o czar achar conveniente. Além das tropas que já estão armadas, ele dificilmente conseguirá colocar muitos mais de pé e dificilmente no momento certo. $\mathrm{O}$ experimento com o serviço militar universal pode custar caro à Rússia.

E então, se se tratar de guerra, ao longo da fronteira de Kovno a Kaminiets, o exército russo estará em país inimigo ali mesmo, em seu próprio solo, entre poloneses e judeus, o governo czarista tendo feito inimigos mortais dos judeus ele mesmo. No momento em que a Rússia perder algumas batalhas, o campo de batalha será recuado de Vístula para Dvina e Dnieper; na retaguarda do exército alemão, sob sua proteção, um exército de aliados poloneses será formado; e será uma punição justa para a Prússia se for obrigada a restaurar uma Polônia forte para garantir sua própria segurança.

Até agora, consideramos apenas as condições diretamente militares, constatando que a Rússia pode ser desconsiderada no que diz respeito à presente questão. Isso se tornará ainda mais evidente, no entanto, assim que dermos uma olhada na situação econômica geral e, principalmente, na posição financeira, na Rússia.

\section{$V I$}

A situação interna na Rússia está quase nas raias do desespero no momento. A emancipação dos servos em 1861 e o desenvolvimento da indústria capitalista em larga escala relacionada a ela, em parte como causa, em parte como efeito, lançaram esse, o mais estável de todos os países, a China europeia, em uma revolução econômica e social que está agora procedendo inexoravelmente seu caminho; e seu progresso é, por enquanto, esmagadoramente devastador. 
À época da emancipação, a nobreza recebia compensação em títulos de empréstimos do Estado, que gastavam em folia o mais rápido possível. Quando isso foi feito, as novas ferrovias abriram um mercado para a madeira das suas florestas; eles cortaram a madeira e a venderam e mais uma vez viveram em esplendor e prazer enquanto durou o produto. A gestão das propriedades sob as novas condições e com trabalhadores livres geralmente foi conduzida da maneira mais insatisfatória; não admira que a nobreza russa, proprietária de terras, esteja endividada, se não totalmente falida, e que os produtos produzidos por suas propriedades estejam diminuindo ao invés de aumentar.

O camponês geralmente recebia terras piores e menores do que possuía até então; ele perdeu o direito ao pastoreio comum e ao uso da floresta e, portanto, a base para a criação de gado. Os impostos foram aumentados consideravelmente e agora tinham que ser pagos em toda parte pessoalmente por eles em dinheiro; além disso, havia as parcelas - também em dinheiro - para pagar os juros e o capital do dinheiro do resgate adiantado pelo estado (выкуп) ${ }^{18}$. Em suma, a deterioração de sua posição econômica geral foi agravada pelo fato de ele ser repentinamente removido à força de uma economia agrícola de subsistência e colocado em uma economia monetária, o que é o suficiente para arruinar o campesinato de um país. O resultado disso foi o desenvolvimento exuberante da exploração dos camponeses pelos proprietários rurais, fazendeiros abastados e proprietários de tavernas, мирожеА (literalmente "comedores de comunidades"19) е кулаки (usurários ${ }^{20}$ ). E como se isso não bastasse, surgiu a moderna indústria em larga escala e arruinou a economia de subsistência dos camponeses até seu último pedaço. A concorrência não só prejudicou a produção industrial doméstica do camponês para seus próprios desejos, como também retirou o mercado de seu artesanato destinado à venda, ou o colocou, na melhor das hipóteses, sob o domínio do "empreendedor" capitalista ou, até pior, de seu intermediário. O camponês russo, com sua agricultura primitiva e seu antigo sistema comunitário protocomunista, fora repentinamente colocado em colisão com a forma mais avançada da moderna indústria em larga escala a qual teve que adquirir à força um mercado doméstico; uma situação em que ele estava irremediavelmente destinado a perecer. Mas o campesinato compreendia quase nove décimos da população da Rússia, e a ruína do camponês era sinônimo - pelo menos temporariamente - da ruína da Rússia. ${ }^{21}$

Após esse processo de agitação social por cerca de vinte anos, outros resultados também surgiram. O desmatamento implacável destruiu os estoques de água do subsolo, a água da chuva e da neve fluiu rapidamente ao longo dos córregos e rios sem ser absorvida, produzindo graves inundações; mas, no verão os rios se tornaram rasos e o solo secou. Em muitas das áreas mais férteis da Rússia, o nível da água do subsolo caiu um metro inteiro, de modo que as raízes das plantações de milho não conseguem mais alcançálo e murcham. Portanto, não apenas os seres humanos foram arruinados, mas em muitas áreas o mesmo acontece com a própria terra por pelo menos uma geração.

Esse processo até agora crônico de ruína tornou-se agudo e, portanto, visível para o mundo inteiro pela fome de 1891. E por esse motivo a Rússia não consegue escapar da fome desde 1891. Esse ano ruim arruinou amplamente os últimos e mais importantes meios de produção dos camponeses - o gado - e elevou seu endividamento a tal ponto que ele acabará com seus últimos ímpetos de resistência. 
Numa posição como esta, um país não poderia fazer mais do que embarcar em uma guerra de desespero. Mas até os meios para isso estão faltando. Na Rússia, a nobreza vive com dívidas, o camponês agora também vive com dívidas, e o Estado, especialmente, vive com dívidas. A quantidade de dinheiro devida pelo estado russo no exterior é desconhecida: mais de quatro bilhões de marcos. A quantia que deve em casa não é conhecida por ninguém; em primeiro lugar, porque nem o total dos empréstimos levantados nem o do papel-moeda em circulação são conhecidos e, em segundo lugar, porque o valor desse papelmoeda muda todos os dias. Mas uma coisa é certa: o crédito da Rússia no exterior está esgotado. Os quatro bilhões de marcos dos títulos da dívida nacional russa inundaram o mercado monetário da Europa Ocidental e o deixaram a ponto de explodir.

A Inglaterra se livrou da maior parte dos "Russos" dela há muito tempo, e a Alemanha o fez recentemente. Holanda e França arruinaram sua digestão comprando-os, como ficou evidente no último empréstimo russo em Paris: apenas 300 dos 500 milhões de francos puderam ser alocados e o ministro russo das Finanças teve que levar de volta 200 milhões aos banqueiros subscritores ${ }^{22}$. Isto constitui prova do fato de que não há perspectiva alguma de um novo empréstimo aos russos no futuro imediato, nem mesmo na França.

Esta é a posição do país que se diz estar nos ameaçando com o risco iminente de guerra e ainda é ainda incapaz de tirar uma guerra de desespero do chão se não formos suficientemente estúpidos para jogar o dinheiro em suas mandíbulas nós mesmos.

A ignorância do governo francês e da opinião pública burguesa francesa que o controla é incompreensível. Não é a França que precisa da Rússia - é a Rússia que precisa da França. Sem a França, o czar e sua política seriam isolados na Europa; impotente, ele teria que deixar tudo no Ocidente e nos Bálcãs seguir seu curso. Com um pouco de bom senso, a França poderia espremer o quanto quisesse da Rússia. Mas, em vez disso, as autoridades francesas estão prostradas diante do czar.

As exportações de trigo da Rússia já foram arruinadas pela concorrência mais barata americana. Isso deixa apenas o centeio como sua principal mercadoria de exportação o qual vai quase exclusivamente para a Alemanha. No momento em que a Alemanha começar a comer pão branco em vez de pão preto, a atual Rússia oficial czarista-grande-burguesa falirá.

\section{VII}

Agora, criticamos suficientemente nossos plácidos inimigos vizinhos. Mas como são as coisas em casa?

Bem, para sermos francos: uma redução gradual no tempo de serviço só pode ser vantajosa para o exército se for posto um fim de uma vez por todas nos maus-tratos a soldados que ganharam terreno nos últimos anos e se tornaram a regra no exército, muito mais do que as pessoas querem admitir.

Esse maus-tratos são a contrapartida das marchas e dos exercícios de parada; os dois sempre se espalharam no exército prussiano assim que este se tornou um exército de tempos de paz e dos prussianos foi repassado para os saxões, bávaros etc. É um legado genuíno da era "velha prussiana" quando o soldado 
era um vagabundo alistado ou o filho de um camponês, e, portanto, tinha que suportar todas as formas de maus-tratos e degradação de seu oficial Junker ${ }^{23}$ sem murmurar. E particularmente a nobreza maltrapilha e sanguessuga, que de maneira alguma está sub-representada a leste do Elba, ainda fornece sua parcela dos piores atormentadores até hoje, e só é igualada nesse respeito pelos filhinhos esnobes da burguesia ansiosos para brincar de Junker.

O espancamento do soldado nunca desapareceu completamente no exército prussiano. Mas costumava ser mais raro, mais brando e às vezes mais engraçado. Mas então, por um lado, tornou-se necessário ensinar cada vez mais o soldado, enquanto, por outro lado, ninguém pensava em abolir os destroços inúteis dos exercícios táticos obsoletos, que se tornaram sem sentido. A partir de então, o oficial não comissionado recebeu cada vez mais autorização tácita para adotar qualquer método de treinamento que julgasse adequado. Ainda mais, ele foi indiretamente obrigado a empregar meios forçados pela ordem de inculcar uma coisa ou outra em seu esquadrão, com um resultado satisfatório em um período limitado. Além de tudo isso, o direito de queixa do soldado é uma zombaria - não é de admirar que o método favorito da Velha Prússia tenha voltado à moda onde quer que seja que os soldados o tolerassem. Pois estou certo de que há muito menos tormento de soldados nos regimentos ocidentais ou naqueles com uma forte mistura de habitantes das cidades do que naqueles que são principalmente constituídos por pessoas do campo a leste do Elba.

Costumava haver um meio de contrabalançar isso, pelo menos na prática. Com o carregador de boca lisa, era simples jogar uma pedrinha no cano sobre o cartucho em branco durante as manobras, e não era incomum que superiores odiados sofressem disparos acidentais durante as manobras. Às vezes dava errado: eu conheci um jovem de Colônia que foi morto dessa maneira em 1849, por um tiro destinado ao seu capitão. Agora, com o carregador de culatra de pequeno diâmetro, não é mais possível fazer isso de maneira tão fácil e discreta; por esse motivo, as estatísticas de suicídio do exército nos indicam o nível barométrico de soldados atormentados com bastante precisão. Mas se o cartucho ativo é colocado em uso em "casos graves", certamente existem todos os motivos para se perguntar se a antiga prática está novamente encontrando seus advogados - como se diz ter acontecido aqui e ali em guerras recentes; embora, é claro, isso não contribua muito para a vitória.

Os relatos de oficiais ingleses são unânimes em elogiar as relações excepcionalmente boas entre superiores e soldados do exército francês em manobras em Champagne, em 1891. Tais coisas, que tantas vezes vazam do quartel para a imprensa em nosso país seriam bastante impossíveis neste exército. Mesmo antes da Grande Revolução, a tentativa de introduzir o açoitamento prussiano com varas falhou. Mesmo no pior momento das campanhas argelinas e do Segundo Império, nenhum superior teria ousado tratar os soldados franceses tão mal quanto o soldado alemão é tratado diante de nossos olhos. E hoje, após a introdução do serviço militar obrigatório universal, eu gostaria de ver o oficial não comissionado francês que se arriscaria a ordenar que seus soldados esmurrassem os ouvidos ou cuspissem na cara um do outro. Mas que desprezo os soldados franceses devem sentir por seus futuros adversários quando ouvirem e lerem ao que se submetem sem reclamar. E todo cuidado é tomado para garantir que os homens do quartel francês leiam e ouçam tudo sobre isso. 
No exército francês, prevalece o espírito e o relacionamento entre oficiais, oficiais nãocomissionados e soldados que prevalecia na Prússia de 1813 a 1815, e duas vezes levaram nossos soldados a Paris. Em nosso próprio país, no entanto, o estado das coisas está se aproximando rapidamente do de 1806, quando o soldado sequer era considerado um ser humano e era açoitado e atormentado, quando havia um abismo intransponível entre ele e o oficial - e esse estado de coisas levaram o exército a Jena ${ }^{24}$ e ao cativeiro francês.

Fala-se muito sobre o valor decisivo do moral na guerra. No entanto, o que mais é feito em tempos de paz, exceto destruí-lo quase que sistematicamente?

\section{VIII}

Até o momento assumimos que a proposta de uma redução gradual e igualitária do tempo de serviço com uma transição definitiva para o sistema de milícias foi universalmente adotada. Mas a questão principal é: será adotada?

Vamos supor que a Alemanha primeiro apresente a proposta à Áustria, Itália e França. A Áustria aceitará com prazer um prazo máximo de serviço de dois anos e provavelmente o reduzirá ainda mais na prática real. No exército austríaco, parece haver muito menos reticências do que no exército alemão para falar sobre o fato de que o curto prazo de serviço de algumas tropas tenha sido um sucesso. Muitos oficiais afirmam sem rodeios que o Landwehr, que serve apenas por alguns meses, é uma tropa melhor do que a linha; algo a seu favor, estou certo, é que um batalhão do Landwehr pode se mobilizar em 24 horas, enquanto um batalhão da linha requer vários dias. Naturalmente: na linha, eles têm medo de infringir a velha arrogância austríaca; no Landwehr, onde todas as instituições foram criadas recentemente, elas tiveram a coragem de não introduzir tal tradição. De qualquer forma, tanto o povo como o governo da Áustria estão almejando um alívio da carga militar, que é mais facilmente obtida ali reduzindo o tempo de serviço, precisamente por conta de suas próprias experiências.

A Itália também aproveitará a oportunidade com as duas mãos. Está sucumbindo sob a pressão do orçamento militar a tal ponto que a ajuda deve ser trazida e breve. Também aqui, a redução do prazo máximo de serviço é a maneira mais curta e fácil. Pode-se dizer assim: ou a Tríplice Aliança ${ }^{25}$ sofrerá grave pena ou terá que adotar um método que seja mais ou menos equivalente à nossa proposta.

Mas se a Alemanha, apoiada pela aceitação da Áustria e da Itália, apresentar essa proposta ao governo francês, este último será colocado em uma posição muito embaraçosa. Se aceitar a proposta, certamente não piorará sua posição militar relativa. Pelo contrário, teria a oportunidade de melhorar essa posição relativa. Em alguns aspectos, é uma desvantagem para a França o fato de o serviço militar obrigatório universal ter sido introduzido lá há apenas 20 anos. Mas essa desvantagem implica a vantagem de que tudo ainda é novo, que os imbróglios de outrora foram cortados recentemente, que outras melhorias podem ser facilmente introduzidas sem enfrentar a resistência obstinada de preconceitos arraigados. Todos os exércitos são capazes de imensos desenvolvimentos após grandes derrotas. Uma melhor utilização do tempo de serviço estabelecida por tratado seria, portanto, muito mais fácil de se efetivar na França do que 
em outros lugares. Além disso, como o sistema educacional também está em um estado de revolução, assim como o exército, seria possível colocar em prática o treinamento físico geral (e particularmente o militar) dos jovens de forma muito mais rápida e fácil lá do que em qualquer outro lugar. Mas isso significaria um fortalecimento da posição militar da França em relação à da Alemanha. Apesar de tudo isso, é possível e até provável que a tendência chauvinista - o chauvinismo francês é tão estúpido quanto a variedade alemã - seja forte o suficiente para derrubar qualquer governo que adote tal coisa, principalmente se vier da Alemanha. Então, vamos supor que a França se recusa. E então o que?

Então, pelo simples fato de ter feito essa proposta, a Alemanha terá ganho uma tremenda vantagem. Não devemos esquecer: os vinte e sete anos do domínio bismarckiano fizeram a Alemanha ser odiada em todos os países - não sem justificativa. Nem a anexação dos dinamarqueses do norte de Schleswig, nem o rompimento e subsequente malabarismo do artigo do Tratado de Paz de Praga a ele relacionado ${ }^{26}$, nem a anexação da Alsácia-Lorena, nem as medidas mesquinhas contra os poloneses da Prússia, não tiveram absolutamente nada a ver com a restauração da "unidade nacional". Bismarck conseguiu dar à Alemanha a reputação de ser gananciosa por território; os burgueses alemães chauvinistas que expulsaram os austríacos alemães e ainda assim desejam unir a Alemanha fraternalmente acima de tudo "desde o Etsch até o Memel"27, mas gostariam de unir a Holanda, Flandres, a Suíça e as supostas províncias "alemãs" do Báltico da Rússia com o Império Alemão - estes chauvinistas alemães deram a Bismarck toda a assistência possível e com um sucesso tão esplêndido que nenhuma pessoa na Europa confia mais nos "honestos alemães". Onde quer que você vá, encontrará em toda parte simpatia pela França e desconfiança contra a Alemanha, que é considerada a causa do atual perigo de guerra. Tudo isto acabaria se a Alemanha decidisse apresentar a nossa proposta. Seria agir como um pacificador de uma maneira que não deixasse margem para dúvidas. Seria declarar sua disposição de liderar o caminho do desarmamento, como convém com razão ao país que deu o sinal verde para o armamento. Desconfiança se transformaria em confiança, aversão em simpatia. Não apenas o ditado de que a Tríplice Aliança é uma aliança pela paz finalmente se tornaria realidade - o mesmo ocorreria com a própria Tríplice Aliança, que atualmente é uma mera pretensão. Toda opinião pública na Europa e na América tomaria partido da Alemanha. E isso seria uma conquista moral que compensaria amplamente até mesmo as desvantagens militares de nossa proposta que pudessem ser pensadas.

A França, por outro lado, tendo recusado a proposta de desarmamento, entraria na mesma posição desfavorável de suspeita agora ocupada pela Alemanha. Agora todos nós vemos, o filisteu europeu diria - e é ele quem é a maior grande potência - agora todos nós vemos quem quer a paz e quem quer a guerra. E se um governo realmente bélico um dia assumir o comando na França, seria confrontado com uma situação que, com um pouco de senso, proibiria positivamente a guerra. Não importa como acontecesse, ficaria para toda a Europa como a parte que havia precipitado e de fato gerado a guerra. Assim, não só teria afastado os pequenos países contra ela, e também a Inglaterra; nem sequer teria certeza da ajuda da Rússia, nem mesmo da ajuda tradicional russa que consiste em primeiro colocar seus aliados em problemas e depois abandonálos em perigo. 
Não esqueçamos: a próxima guerra será decidida pela Inglaterra. A Tríplice Aliança em guerra com a Rússia e a França, assim como a França, separada da Rússia por território inimigo, são todas dependente do transporte marítimo para as grandes importações de grãos que lhes são indispensáveis. A Inglaterra é o mestre absoluto do mar. Se colocar sua marinha à disposição de um lado, o outro simplesmente morrerá de fome, com os suprimentos de grãos cortados; será a fome de Paris ${ }^{28}$ em uma escala imensamente maior, e o lado faminto terá que se render, tão certo quanto dois e dois são quatro.

Tudo certo, então: no momento, a tendência liberal está em vantagem na Inglaterra, e os liberais ingleses têm distintas simpatias pelos franceses. Além disso, o velho Gladstone é pessoalmente um russófilo. Se uma guerra europeia começar, a Inglaterra permanecerá neutra pelo maior tempo possível; mas nas circunstâncias acima mencionadas, mesmo sua neutralidade "benevolente" pode ser de ajuda decisiva para uma das partes em guerra. Se a Alemanha apresentar nossa proposta e ela for rejeitada pela França, a Alemanha não apenas superará todas as simpatias inglesas que se opõem a ela e assegurará a neutralidade benevolente da Inglaterra; mas, também, tornaria praticamente impossível para o governo inglês ingressar na guerra ao lado dos oponentes da Alemanha.

Então, em conclusão:

Ou a França aceita a proposta. Então o risco de guerra decorrente de armamentos cada vez maiores será realmente eliminado, os povos descansarão e a Alemanha desfrutará da glória por ter iniciado isso.

Ou a França não aceita. Tornará então a sua própria posição na Europa pior e a da Alemanha melhor, a tal ponto que a Alemanha não precisará mais temer uma guerra e poderá até mesmo prosseguir para reduzir gradualmente o tempo de serviço e pavimentar o caminho para o sistema de milícias por sua própria iniciativa e livre de perigos, em colaboração com seus aliados, que somente então serão verdadeiramente seus aliados.

Terá a coragem de dar o passo em direção à libertação? Ou vai esperar até a França, esclarecida sobre a posição da Rússia, dar o primeiro passo e colher o crédito para si mesma?

\footnotetext{
Notas:

${ }^{1}$ Escrito em fevereiro de 1893; Prefácio, em 28 de março - Tradução e Notas - João Rafael Chió Serra Carvalho. Nota do Tradutor: Publicado pela primeira vez como uma série de artigos (sem prefácio) no Vorwärts ${ }^{1}$, N. ${ }^{\circ}$. 51-56, 58 e 59, 1-5, 7, 9 e 10 de março de 1893 e, na íntegra, como panfleto no final de março de 1893.

Instado a escrever essa série de artigos após a apresentação no Reichstag de um projeto de lei, pelos partidos do governo, visando o aumento do orçamento militar, Engels, tentou, ao lutar pelo slogan de um serviço militar universal formado por uma milícia civil, demonstrar ao Partido como tal milícia poderia servir para, a partir do medo popular cada vez mais crescente de uma nova guerra e do custo econômico da corrida armamentista, organizar as massas populares sob uma bandeira que afastaria a necessidade de uma aliança na Assembleia com setores liberais e conservadores.

Nos artigos, formalmente apresentados como se escritos por um especialista militar, sóbrio e realista, Engels argumenta ser militarmente possível deixar a defesa da nação em mãos de uma milícia civil cujo termo de serviço fosse encurtado em relação ao praticado à época. Argumenta, ademais, que o termo prolongado de serviço bem como a forma do aproveitamento deste tempo era não somente antieconômico, mas, militarmente ineficiente.

Sua proposta, a convenção de um congresso internacional para a substituição em toda a Europa dos Exércitos da época por milícias civis com um tempo pré-estabelecido de circunscrição, tomada por muitos historiadores contemporâneos como utópica ${ }^{1}$, era precisamente fundada no profundo conhecimento militar de Engels que percebia nessa substituição a única forma possível de refrear a corrida armamentista que assolava o Ocidente e
} 
desaguaria, mais cedo ou mais tarde, em uma guerra mundial sem precedentes.O tradutor é Formado em História pela UFMG, Mestre em História Social pela USP, Doutorando em História Social da Cultura pela UFMG, educador popular e militante do Partido Comunista Brasileiro. Orcid: https://orcid.org/0000-0001-5864-9046, assimdisseojoao@gmail.com

2 28.11.1920 - 05.08.1895. F undador, juntamente com Marx, do socialismo cientifico e expositor brilhante de sua filosofia: o materialismo dialético. Seu pai era fabricante de tecidos, e a difícil situação dos operários da fabrica paterna bem cedo feriu a sua sensibilidade. Nas Cartas de Buppertal, que escreveu em 1839, descrevia e criticava as condições de miséria em que viviam os trabalhadores da industria têxtil alemã. Democrata, revolucionário, desde muito jovem ingressou Engels no movimento socialista. Em 1842, transferindo-se para Londres, acompanhou de perto a luta cartista, e aí realizou o seu famosa estudo sobre a Situação da Classe Operaria na Inglaterra, publicado em 1845. Já antes, em 1844, publicara um trabalho critico sobre a Economia Politica, nos Anais Franco-Alemães, revista editada em Paris por Marx e Ruge. Em ambos esses trabalhos formulara Engels alguns dos elementos teóricos do socialismo cientifico. Cheglov observa que Engels chegou, como $\underline{\text { Marx }}$, ao comunismo e ao materialismo antes de sua colaboração comum, isto é, independentemente um do outro. Conheciam-se desde 1841, por troca de cartas, sendo Engels colaborador do jornal de Marx, a Gazeta Renana. O primeiro encontro pessoal de ambos se verificou em Colonia, quando aquele seguia para a Inglaterra. Mas desde então se ligaram para o resto da vida, irmanados pel* mesmo destino e por uma amizade sem exemplo em homens de tal porte. "Em fins de setembro de 1844, Engels escreve a Marx, de Barmen, onde vivia a sua família e onde ele nascera. Ainda não tinha Engels completado seus 24 anos. Aborrecia-se da vida no seio da família e procurava escapar de seu controle. Seu pai, autoritário, industrial cheio de convicções, revoltava-se de ver seu filho frequentar reuniões politicas e professar ideias comunistas. "Se não fosse por causa de minha mãe, que é um belo espi- rito e a quem amo verdadeiramente... escreve Engels - eu não saberia como permanecer aqui, durante as poucas semanas que ainda me restam... Não podes imaginar - lamenta-se ele — as considerações mesquinhas e as crenças supersticiosas com que me cercam. (Correspondance $K$. Marx-Engels, tomo I, pág. 2). Durante o tempo em que ainda esteve em Barmen, onde o reteve também, por algum tempo, uma aventura romanesca, ele cede à pressão de seu pai e vai trabalhar, durante uma quinzena, nos escritórios da fabrica pertencente a seu progenitor. "O comercio causa-me horror... Barmen e a perda de tempo me horrorizam, mas o que, acima de tudo, me aborrece é continuar não um simples burguês, mas um fabricante, um burguês que intervém ativamente contra o proletariado. Eu me consolo, continua Engels, trabalhando em meu livro sobre a situação da classe operaria". (Ibidem — pág. 23). "Pode-se estar, na qualidade de comunista, à par com a sua situação exterior, burguês e traficante, quando nada se escreve; mas fazer propaganda comunista em grande escala e, ao mesmo tempo, ocupar-se de comercio e de industria, eis o que não está bem. Já estou esgotado. Vou-me embora por ocasião da Pascoa. Acrescente-se a isto, a vida cansativa no seio de uma família prussiana, radicalmente cristã: se isto continua, acabarei por me tornar um filisteu alemão e levarei comigo os estigmas para o comunismo". (Ibidem — págs. 23-24) Eis o que escrevia o jovem Engels Depois da revolução de 1848, a vida obrigou-o a voltar ao escritório de seu pai, para se entregar, por longos anos, a "este cão de comércio". Mas ele se houve bem, criando em torno de si uma atmosfera, não de prussianismo cristão, mas uma toda diferente uma atmosfera de camaradagem, e soube tornar-se, por toda a vida. o inimigo, implacável da "introdução do filisteísmo no comunismo" (Lénin - Marx, Engels e Marxismo, pág. 182 — Edit. Calvino Ltda. — 1945). Data de 1844-1845 a primeira obra de colaboração entre os dois: A Sagrada Família, polemica dirigida contra os hegelianos de esquerda e particularmente contra os irmãos Bauer: "Criticando o idealismo dos hegelianos, Marx e Engels reelaboraram materialisticamente a dialética de Hegel Descobriram as leis da dialética na realidade objetiva, na historia humana* demonstraram que a verdadeira força da historia humana reside, não no automovimento da ideia, mas no movimento das massas" (A. Cheglov) Nessa obra se encontram os fundamentos do materialismo dialético e da interpretação materialista da historia, sem embargo de ainda conservar certos vestígios da influência feuerbachiana. $\mathrm{Na}$ obra que se seguiu, também realizada em colaboração, $A$ Ideologia Alemã, é que eles se libertam da influência hegeliana e feuerbachiana, aparecendo como pensadores emancipados e seguros de sua própria concepção. Lembremos que A Ideologia Alemã, escrita em 1845-1846, não encontrou na época nenhum editor disposto a publicá-la, daí sua publicação recentemente - em 1932, na URSS. "1846. Engels está em Paris Nesta época, Paris inteira dedicase à politica e à discussão das diferentes teorias socialistas. Engels estuda com avidez o socialismo, conhece pessoalmente Cabet, Louis Blanc, e outros socialistas de evidencia, frequenta as redações e outros círculos. Sua atenção dirigese principalmente para a doutrina socialista mais seria e mais divulgada nesses tempos, o proudhonismo Antes mesmo do aparecimento de $A$ Filosofia da Miséria, de Proudhon (outubro de 1846; Marx respondeu-lhe pela sua celebre Miséria da Filosofia, aparecida em 1847), Engels faz uma critica mordaz, impiedosa e com uma notável profundeza, sobre as ideias mestras de Proudhon, que, então, exaltava particularmente o socialista alemão Grün O perfeito conhecimento do inglês e da literatura inglesa, que Marx não assimilou, senão mais tarde, permite a Engels (carta de 18 de setembro de 1846) assinalar, com segurança, os exemplos da falência na Inglaterra, das famosas "lojas de trabalho" proudhonianas. Proudhon calunia o socialismo - diz Engels, cheio de indignação, - pois de acordo com Proudhon os operários devem redimir o capital. Já com 26 anos, Engels destrói, literalmente, o "socialismo verdadeiro" - achamos essa expressão em sua carta de 23 de outubro de 1846, muito tempo antes do Manifesto do Partido Comunista, - socialismo cujo principal representante, a seu modo de ver, é Grün. Uma doutrina anti-proletária, pequeno-burguesa, de "vagabundos", de "frases ocas", toda especie de tendências "humanitárias", o "medo supersticioso" do "comunismo de estomago (Loffel-Kommunismus - literalmente: "comunismo da colher"), "planos pacíficos para tornar feliz a humanidade" — é assim que Engels considera o socialismo pré-marxista, em todos os seus aspectos" (Lénin: Marx, Engels e Marxismo). Em 1847, escreveu para a Liga dos Comunistas, cuja sede era em Londres, um projeto de catecismo ou "profissão de fé comunista" (publicado por Bernstein, em 1931, com o titulo de Princípios do Comunismo), que serviu a Marx como base para redigir o celebre Manifesto Comunista, aparecido em fevereiro de 1848, em alemão". "Em sua carta de 24 de novembro de 1847, Engels informava a Marx que tinha esboçado um projeto do_Manifesto Comunista, pronunciando-se, entre outras coisas, contra a forma de catecismo que anteriormente se tinha pretendido dar. "Começo pela questão, escreve Engels, que é o comunismo? Passo, logo a seguir, ao proletariado: origem, o que o diferencia dos trabalhadores antigos, desenvolvimento da oposição entre o proletariado e a burguesia, crises, consequências... e, finalmente, a politica do Partido Comunista". (Correspondance K. Marx-F. Engels, tomo I, pág. 138). "Esta carta histórica de Engels sobre o primeiro esboço de uma obra que fez a volta ao mundo e que, até o presente, é justa em tudo o que há de mais essencial, viva e atual, como se tivesse sido escrita ontem, mostra claramente que se tem razão em colocar, lado a lado, os nomes de $\underline{\text { Marx }}$ e de Engels, como fundadores do socialismo contemporâneo". (Lénin — Pravda, n. 268, de 28 de novembro de 1920). Obrigado por suas atividades comerciais, residiu durante vinte anos em Manchester, de onde colaborou em diversas publicações estrangeiras e 
prestou a Marx o auxilio material necessário para que se pudesse dedicar ao seu trabalho de investigação. A partir de 1870, época em que abandonou Manchester para se estabelecer em Londres, começou a desenvolver intensa atividade dentro do movimento operário Incorporado ao Conselho diretor da Primeira Internacional, da qual foi um dos fundadores, como $\underline{\text { Marx }}$, encabeçou com o seu amigo a luta contra a tendencia anarquista de Bakúnin e reservou para si a missão de difundir e esclarecer, em face das mais diversas questões, as ideias do socialismo marxista. Fruto deste trabalho foi uma série de obras notáveis, entre as quais se destacam O Problema da Moradia (Zur Wohnungsfrage, 1874) e o celebre Anti-Dühring (1878), considerado como "a obra mais importante produzida pelo socialismo moderno, depois de $\underline{\boldsymbol{O}}$ Capital. "Inspirando-se nas mesmas ideias que Marx e colaborando intimamente com ele, Engels, em todas as suas obras filosóficas, opõe, da mesma forma, clara e sucintamente, a respeito de todas as questões, as duas tendencias, materialista e idealista, sem tomar a serio, nem em 1878, nem em 1888, nem em 1891, as inúmeras tentativas feitas por muitos para "superar" o "exclusivismo" do materialismo e do idealismo, para afirmar uma nova tendência, quer se tratasse do "positivismo", do "realismo", ou qualquer outro charlatanismo professoral. Toda a sua campanha contra Dühring, Engels a fez, procurando a aplicação consequente do materialismo e acusando o materialista Dühring de confundir a questão com palavras, de cultivar frases, de usar processos de raciocínio que implicam numa concessão ao idealismo, na passagem a posições idealistas. Ou o materialismo, consequente até o fim, ou a mentira e a confusão do idealismo filosófico, esta é alternativa apresentada em cada um dos parágrafos do "Anti-Dühring"; e os indivíduos de cérebros embebidos na filosofia professoral reacionária ficaram sozinhos, sem sequer se aperceber. Até 1894, data em que escreveu o seu ultimo Prefácio para o Anti-Dühring, cuja revisão acabava de fazer e que então tinha recebido o seu ultimo retoque, Engels, que se mantinha a par da filosofia nova e dos progressos das ciências naturais, não deixou de insistir com a máxima decisão nas suas concepções, claras e firmes, varrendo a poeira dos novos sistemas, grandes e pequenos. O fato de que se tenha posto ao par de tudo o que diz respeito à filosofia moderna, verifica-se por seu livro Ludwig Feuerbach. Menciona mesmo, no prefacio de 1888 a esse livro, um detalhe como o do renascimento da filosofia clássica alemã na Inglaterra e na Escandinávia; quanto ao neo-kantismo dominante e quanto à doutrina de Hume, Engels não demonstra por eles (no seu Prefácio como no próprio texto do livro) senão o mais profundo desprezo. É evidente que Engels, observando a repetição dos velhos erros de Kant e Hume, anteriores a $\underline{\text { Hegel, }}$ por parte da filosofia alemã e inglesa em voga nesse período, se tenha mesmo inclinado a esperar algum beneficio de uma volta à Hegel (na Inglaterra e na Escandinávia), esperando que esse grande idealista e dialético contribuísse para dissipar os erros primários do idealismo e da metafisica. Sem se dedicar ao exame das inúmeras nuançes do neo-kantismo na Alemanha, e da doutrina de Hume na Inglaterra, Engels condena, em primeiro lugar, o abandono decisivo do materialismo por parte desses filósofos. Qualifica toda a tendencia dessas duas escolas como um recuo cientifico. Como considerava ele a tendencia, inegavelmente "positivista", de acordo com a terminologia corrente, inegavelmente "realista", desses neokantistas e desses partidários de $\underline{\text { Hume}}$ entre os quais não poderia ignorar, por exemplo, um Huxley? Engels considerava que o "positivismo" e o "realismo", que seduziam e seduzem ainda uma grande quantidade de confusionistas imitadores, eram, no melhor dos casos, um procedimento de filisteu, que consistia em introduzir sub-repticiamente o materialismo, que acabava de ser renegado e refutado, gritantemente. Basta refletir um momento sobre essa apreciação a respeito de Huxley, esse naturalista de fama, esse realista seguramente muito mais realista, esse positivista seguramente muito mais positivista que $\mathbf{M a c h}$, Avenarius, e comparsas, para se aquilatar quanto desprezo poderia fazer nascer em Engels a mania de um punhado de marxistas de hoje, que se colocam a favor do "positivismo mais moderno", ou do "realismo mais moderno", etc. (Lénin - Marx-Engels, Marxismo, págs. 449-50). Desde a morte de Marx, em março de 1883, foi reconhecido como a mais alta autoridade, do movimento socialista internacional, a quem procuravam, em busca de conselho, os dirigentes social-democratas de todos os países. Referindo-se às frequentes visitas que ele recebia em sua casa, em Londres, escreveu Bonnier as seguintes palavras: "Todos aqueles, e eram muitos, que o visitavam na Regent's Park Road, lembramse da cordialidade com que eram recebidos, fosse qual fosse a graduação de cada qual no exército socialista. Desde os luta dores que se acham na primeira linha de combate, publicistas e oradores, até aos simples soldados da causa, eram todos acolhidos com igual atenção e todos saiam dali, daquelas conversações com o amigo e companheiro de Marx, sentindo-se mais firmes em suas ideias e cheios de maior coragem". Pertencem a esse período seu livro, publicado em 1884, sobre $\boldsymbol{A}$ Origem da Família, da Propriedade Privada e do Estado, um notável ensaio publicado em Neue Zeit com o titulo de Feuerbach e o Fim da Filosofia Clássica Alemã (1886), bem como um sem numero de artigos aparecidos nas revistas da social-democracia europeia. Por sua excepcional compreensão da ideologia de $\underline{\text { Marx }}$, era talvez o único que podia realizar a importante e difícil tarefa de publicar os livros segundo e terceiro de $\boldsymbol{O}$ Capital, que aquele havia deixado inconclusos; estes volumes apareceram em 1885 e 1894 , respectivamente. Pouco tempo depois escreveu um interessante complemento do livro terceiro que, figura como "Apêndice" no volume correspondente. Até a morte, sobrevinda em Londres (5 de agosto de 1895), conservou integra a capacidade de trabalho. A morte veio surpreendê-lo quando se preparava para escrever a historia da Primeira Internacional. Suas cinzas foram lançadas ao Mar do Norte. Sobreviveu doze anos a Marx. Após a morte de Marx, em 1883, tornou-se o chefe espiritual reconhecido e de maior autoridade no movimento operário internacional. Para detalhes sobre sua pessoa, sua vida e sua obra, consultar sobretudo: Geschichte der deutschen Sozial-Demokratie, 1921, (História da Social-Democracia Alemã), de Franz Mehring; Karl Marx, Geschichte seines Lebens, 1920; (Karl Marx, História de sua vida), do mesmo autor; Friedrich Engels in seiner Frübzeit, 1820 bis 1851, (Friedrich Engels em sua juventude, 1820-1851), de Gustav Mayer, e Friedrich Engels Brevier, 1920 (Breviário de Friedrich Engels), de Ernst Drahn. O grande mérito de Engels está na exposição e no desenvolvimento do materialismo dialético. Entre suas obras teóricas, cabe o primeiro lugar aos ensaios filosóficos São obras primas que exerceram sobre o pensamento do proletariado a mais duradoura influência e, até hoje, não só nada perderam de seu valor cientifico, mas, ao contrário, adquiriram importância crescente. Engels mostra, nessas obras, com uma mestria e uma clareza incomparáveis, as relações dialéticas da filosofia com as lutas de classes sociais e com o desenvolvimento das forças produtivas e da libertação paralela das ciências da natureza. Desse modo, leva o leitor por caminhos sempre novos a esta verdade de que, se há uma filosofia, que liberta realmente a humanidade inteira, não pode ser senão a filosofia do materialismo dialético, porque somente ela é capaz de preservar o pensamento teórico contra o Scylla do idealismo e o Caribdes do materialismo vulgar mecanicista, bem como de assegurar a vitoria a uma teoria materialista consequente do conhecimento. Suas obras fundamentais, que constituem já há muito tempo a solida base ideológica de todos os operários conscientes, são: Herrn Eugen Dühring's Sumwälzung der Wissenschaft, 1878 (12.a ed., 1923), (A subversão da ciência pelo Sr. Eugen Dübring), obra polemica composta à maneira de Lessing, viva, atraente e de vigor combativo, uma defesa absolutamente fecunda e inigualável da concepção materialista do mundo; Ludwig Feuerbach und der Ausgang der klassischen deutschen Philosophie, 1888 (Ludwig Feuerbach e o fim dafilosofia clássica alemã)), excelente ensaio sobre o

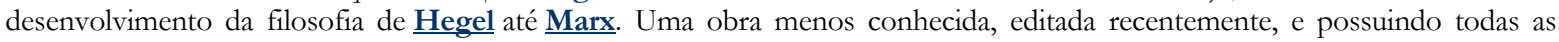


qualidades que fizeram do Anti-Dühring a principal arma dos marxistas na luta contra os novos sistemas idealistas de filosofia e contra todos os falsificadores de Engels, é Natur und Dialektik (Dialética e Natureza), coletânea de artigos e fragmentos em grande parte inéditos, escritos de 1873 a 1892, constituindo o segundo volume do Arquivo Marx-Engels (Moscou, 1925). Essa obra é uma fonte inesgotável para todos os que se interessam pela luta pelo materialismo dialético e por sua justa interpretação e estejam convictos da necessidade de incorporar harmoniosamente ao marxismo os resultados das ciências naturais modernas. Vejamos, entre suas outras obras teóricas e metodológicas, as mais importantes. Em colaboração com Marx: Marx und Engels über Feuerbach (Marx e Engels sobre Feuerbach), primeira parte da Deutschen Ideologie (Arquivo Marx-Engels, vol. I, 1926); Grundsätze des Kommunismus (Princípios do comunismo), 1844 (nova edição de Eduard Bernstein, 1914); em colaboração com Marx: Manifest der kommunistischen Partei (Manifesto do Partido Comunista) 1848 (nova edição Viva-Verlag, 1923) ; Die entwicklung des Sozialismus von der Utopie zur Wissenschaft (Do Socialismo utópico ao socialismo cientifico) 1883 (nova edição Viva-Verlag, 1924); Der Ursprung der Familie, des Privateigentums und des Staats (A origem da família, da propriedade privada e do Estado) 1884 (22.a edição, 1922); Zur Geschichte des Urchristentums (Contribuição à historia do cristianismo primitivo), Neue Zeit, 1804-1895. Ainda mais: Aus dem literarischen Nachlass von Karl Marx und Friedrich Engels (extratos da obra literária de Karl Marx e Friedrich Engels), organizados por Franz Mehring (3. ${ }^{a}$ edição, 1920). O estudo de sua rica correspondência é igualmente indispensável. Indicamos antes de tudo: Briefiwechsel zwischer, Friedrich Engels und Karl Marx (Correspondência entre Friedrich Engels e Karl Marx), 1844-1883, editada por August Bebel e Eduard Bernstein em 1913; Briefe und Auszüge aus Briefen von Joh. Phil. Becker, Jos Dietzgen, Friedrich Engels, Karl Marx u. a. an F. A. Sorge und andere (Cartas e extratos de cartas de John. Phil. Becker... e outros), 1906, e Die Briefe von Friedrich Engels and Eduard Bernstein (Cartas de Friedrich Engels e Eduard Bernstein), publicadas por Eduard Bernstein em 1925. Fonte: Marxist Internet Archive - Dicionário. Disponível em: https://www.marxists.org/portugues/dicionario/verbetes/e/engels.htm Acesso em: 13.01.2021 07:28

3 Mantido no original em alemão. Landwehr ou Landeswehr é um termo de língua alemã usado para se referir a certos exércitos nacionais ou milícias encontradas na Europa do século XIX e início do século XX. (N.T)

${ }^{4}$ Nos países de língua alemã, o termo Landsturm foi historicamente usado para se referir a milícias ou unidades militares compostas por tropas de qualidade inferior. Está particularmente associado à Prússia, Alemanha, Áustria-Hungria, Suécia e Holanda. (N.T)

5 Expressão usada pelos italianos para descrever o ardor dos franceses durante a Batalha de Fornovo, em julho de 1495. (N.T) Itálico nosso.

6 A seção da reserva no exército da Prússia e posteriormente no da Alemanha composta por homens da idade selecionável que durante períodos de paz tiveram seu serviço militar na ativa posposto. O tempo de serviço na ersatzreserve foi estabelecido em 12 anos em 1874, ela era usada para reforçar o exército em tempo de mobilização (N.T)

${ }^{7}$ Darmsessianos se refere aos habitantes de Darmstadt que a época era um ducado comandado pela Casa de Hesse (N.T)

${ }^{8}$ Em 1867 com a formação da Confederação da Alemanha Setentrional sob o comando da Prússia a região de Hesse-Darmstadt adotou o sistema militar prussiano (N.T)

${ }^{9}$ Instrumento de punição usado contra soldados, trata-se de um chicote de múltiplos fios, usado para açoitamento. (N.T), itálico nosso.

${ }^{10}$ Kupfergraben é um canal localizado em Berlim próximo ao qual se localizava o sítio onde Engels prestou seu serviço militar como voluntário entre 1841-1842 (N.T)

11 Trata-se de Frederico II que governou o Reino da Prússia de 1740 a 1786, o reinado mais longo de qualquer rei Hohenzollern, durando um total de 46 anos. (N.T)

12 A referência é à viagem de Engels a Barmen em abril de 1860 para o funeral de seu pai. (N.T)

13 Engels está se referindo ao editorial "ein alter Kunstgriff" (Um velho truque). O editorial criticou o novo projeto de lei militar. (N.T)

14 O Artel era uma associação na Rússia pré-revolucionária de pequenos produtores para atividades comerciais em comum (pedreiros, artesão, marceneiros, etc.) (N.T)

15 Optamos por transliterar em cirílico o original russo uma vez que na sequência o próprio Engels já fornece sua tradução, a saber, responsabilidade mútua

16 A palavra russa "ополчение", transliterada por nós em cirílico, pode ser traduzida por milícia ou menos frequentemente por guarda nacional e seria o equivalente ao landwehr germânico. (N.T)

17 A palavra russa “чино́вники”, transliterada por nós em cirílico, pode ser traduzida por oficial e era usada a época para denominar todo o grupo de funcionários públicos. (N.T)

18 A palavra russa выкуп, transliterada por nós ao cirílico, pode ser traduzida por "resgate" ou "recompra" e simboliza a necessidade de pagamento ao Estado por parte do campesinato russo dos adiantamentos feito em dinheiro para a produção (N.T)

19 A palavra russa мирожеА, transliterada por nós ao cirílico, pode ser traduzida literalmente por "aquele que come a paz", Engels já fornece uma excelente tradução na sequência (N.T)

20 A palavra russa кулаки, transliterada por nós ao cirílico, possui como tradução literal "punhos" e é uma metáfora dos punhos cerrados por onde o dinheiro não passa, portanto, a tradução proposta por Engels na sequência de usurários é mantida por nós (N.T)

${ }^{21}$ Engels já havia abordado este tema no artigo Der Sozialismus in Deutschland (O socialismo na Alemanha), publicado na revista do SPD, Die Neue Zeit (O Novo Tempo), n¹9, vol.1, 1891-1892 (N.T)

22 A referência é ao empréstimo tentado pelo governo russo em Paris que prometia pagar 3\% de lucro. Em um primeiro momento a operação foi um sucesso e se conseguiu 7,5 vezes a soma inicial pretendida de 500 milhões de francos. Porém, com a queda do papel-moeda russo nos mercados europeus e a subsequente fome de 1891 aqueles que haviam se subscrito à operação exigiram o seu pagamento e o governo russo teve que levantar fundos prontamente o que diminuiu consideravelmente o sucesso da operação financeira reduzindo seu saldo a quase metade do valor inicialmente pleiteado. (N.T) 
${ }^{23}$ Como eram denominados os membros da nobreza constituída por grandes proprietários de terras e militares de elite nos estados alemães anteriores e durante o $2 .^{\circ}$ Reich (1871-1918). (N.T)

${ }^{24}$ A referência de Engels é a série de batalhas com clamorosas derrotas prussianas e esmagadoras vitórias da França sob o estandarte de Napoleão. (N.T)

${ }^{25}$ Bloco político e militar formado por Itália, Áustria-Hungria e Alemanha contra a França e a Rússia cuja forma final surgiu em 1882. (N.T)

26 O Tratado de Paz de Praga, assinado em 1866 concluiu a guerra austro-prussiana. Por ele foi permitida a formação da Confederação da Alemanha Setentrional encabeçada pela Prússia e foi cedida a Prússia o direito sobre Schleswig-Holstein cuja posse havia sido tirada da Dinamarca por ambos os países que a comandavam em comum. Tal província deveria ser devolvida à Dinamarca após plebiscito com sua população, mas a Prússia se recusou a fazê-lo. Em 1875 o artigo V, que continha essa disposição, foi anulado (N.T)

27 Uma paráfrase de Lied der Deutschen de Hoffmann von Fallersleben, escrito pelo linguista para se tornar um hino do povo alemão unificado. O termo significa literalmente Canção dos Alemães. (N.T)

${ }^{28}$ Engels se refere à fome de Paris durante a Guerra Franco-Prussiana de 1870-1871 (N.T) 